\title{
ANALISIS KEWENANGAN PEMERINTAH DESA DALAM BIDANG KEMASYARAKATAN: STUDI DI DESA TOKA KECAMATAN BULIK TIMUR KABUPATEN LAMANDAU
}

\author{
Ambri Semet
}

\begin{abstract}
Results of the study are (1) the execution of the authorities of the Government of the village of Toka in the field of development could be said to be doing well, one of them empirically though the village of Toka is one of the villages that are a bit far from the District of the city, but according to the results of the interview with the head of the village and the surrounding communities say if their area could be said to have never experienced a serious thing about events that interfere with their village. Then one form of civic activities was coaching against the participation of the citizens. The form of Participation in the village of Toka researchers can see namely the participation of government directives and from Community initiatives itself clearly visible. However, in essence community involvement village of Toka is big enough in carrying out various activities of social mutual clearly still visible in the village. (2) the Government authority went on supporting Factors village of Toka is to Coaching against the BPD. Factors restricting implementation of the Government of the village is village of Toka Government does not attempt to establish coordination with the mengitensifkan and Binmas and Babinsa, especially in the peace and order of the villagers either from the election of the village chief or in terms of the construction of public security of the village of Toka. This mostly happens in rural areas, because of the large number of societies that still do not understand about the procedure of manufacture certificate, let alone land that the original owners were their parents who already have no land boundaries so that they have even mutual claimed by the other party.
\end{abstract}

Keywords: authority of the Government of the village, the construction of the participation, the construction of the BPD.

\section{LATAR BELAKANG}

Semenjak gerakan reformasi digulirkan, beberapa tuntutan perubahan terjadi secara besar-besaran. Berbagai sektor kehidupan menghendaki adanya proses penyesuaian menuju tata sosial, politik, ekonomi dan sosial budaya yang lebih baik. Cara-cara demokratis yang mencakup semangat toleransi, pluralisme, penghargaan atas minoritas, kebersamaan dan pengembangan lokalitas mulai menguat kembali. Persoalannya adalah transformasi atas perubahan baru ini ternyata justru tidak berjalan secara cepat, tepat dan relatif normal. Justru berbagai fakta membuktikan bahwa masa transisi cenderung mengisyaratkan adanya benturan-benturan baru.

Kewenangan dalam bidang kemasyarakatan inilah yang menggerakkan masyarakat untuk dapat melakukan sesuatu yang diinginkan oleh pemerintah, khusus di Desa Toka Kecamatan Bulik Timur. Komponen-komponen dan sumber daya yang ada menjadi tanggung jawab pemerintah untuk diberdayakan, khususnya peran dan tanggung jawab pemerintah desa dalam membina keamanan, ketertiban, ketentraman, kerukunan, perdamaian, pengembangan gotong royong, serta 
pembinaan pada organisasi yang ada di masyarakat desa. Sampai sejauh ini sesuai dengan pengamatan awal bahwa pembinaan kemasyarakatan baik pada lingkungan pemuda, bapak, ibu, dan organisasi lainnya yang ada di desa belum maksimal melakukan pemberdayaan dan pembinaan yang seharusnya menjadi tanggung jawab dan kewenangan pemerintah desa. Tentunya hal ini akan berdampak kepada keamanan dan ketertiban masyarakat desa. Seperti pengamatan peneliti stabilitas keamanan dan ketertiban masyarakat Desa Toka Kecamatan Bulik Timur sampai dengan penelitian ini dilaksanakan masih belum stabil, banyak anak-anak muda di Desa Toka yang belum mengerti dan sadar arti penting dari pada stabilitas desa, sejauh itu pula pemerintah desa beserta perangkat-perangkat yang ada belum maksimal melakukan pembinaan kepada generasi muda ini, bukan hanya itu saja tetapi ada beberapa organisasi kemasyarakatan yang belum dimaksimalkan peran dan fungsinya, seperti lembaga masyarakat desa, karang taruna, dan PKK yang semuanya memerlukan perhatian khusus dari pemerintah desa untuk membina, yang seharusnya hal itu merupakan kewenangan pemerintah desa.

Maka dari itu berdasarkan latar belakang diatas, dilakukanlah penelitian dengan Judul "ANALISIS PELAKSANAAN KEWENANGAN PEMERINTAHAN DESA DALAM BIDANG KEMASYARAKATAN (Studi Di Desa Toka Kecamatan Bulik Timur Kabupaten Lamandau)".

\section{LANDASAN TEORI}

\section{Konsepsi Pemerintahan Secara Umum}

Secara etimologis, pemerintahan dapat diartikan sebagai berikut: (a) Memerintah berarti melakukan pekerjaan menyuruh; (b) Pemerintah berarti badan yang melakukan kekuasaan memerintah; (c) Pemerintahan berarti perbuatan, cara, hal atau urusan dari badan yang memerintah. Hal ini menunjukan bahwa pemerintahan merupakan suatu pola kegiatan sebagai pelaksanan dari fungsi negara yang dilakukan oleh unsur atau perangkat negara dalam hubungan antara pemerintah dengan yang diperintah.

\section{Kewenangan Pemerintahan Desa}

Wewenang (kamus Besar bahasa Indonesia, 1995: 205) didefinisikan sebagai kekuasaan membuat keputusan, memerintah, dan melimpahkan tanggung jawab kepada orang lain; fungsi yang boleh tidak dilaksanakan.

\section{Desa dan Pemerintahan Desa}

Desa secara etimologi berasal dari bahasa Sansekerta, deca yang berarti tanah air, tanah asal atau tanah kelahiran. Di Indonesia, istilah desa adalah pembagian wilayah administratif di Indonesia di bawah kecamatan, yang dipimpin oleh Kepala Desa, sedangkan di Kutai Barat, Kalimantan Timur disebut Kepala Kampung atau Petinggi. Desa menurut Prof. Drs. HAW. Widjaja (2003: 3) dalam bukunya "Otonomi Desa" menyatakan bahwa: "Desa adalah kesatuan masyarakat hukum yang mempunyai susunan asli berdasarkan hak asal usul yang bersifat istimewa, landasan pemikiran dalam mengenai Desa adalah keanekaragaman, partisipasi, otonomi asli, demokratisasi dan pemberdayaan masyarakat”. 


\section{Kewenangan Pemerintahan Desa Dalam Bidang Kemasyarakatan}

Kewenangan pemerintah dalam bidang kemasyarakatan sesuai dengan Peraturan Menteri Desa (Permendesa) Nomor 1 Tahun 2015 tentang pedoman kewenangan berdasarkan hak asal usul dan kewenangan lokal berskala desa, Pasal 13 disebutkan bahwa kewenangan lokal berskala desa di bidang kemasyarakatan desa sebagaimana dimaksud meliputi: (a) membina keamanan, ketertiban dan ketenteraman wilayah dan masyarakat desa; (b) membina kerukunan warga masyarakat desa; (c) memelihara perdamaian, menangani konflik dan melakukan mediasi di desa; dan (d) melestarikan dan mengembangkan gotong royong masyarakat desa.

\section{METODE PENELITIAN}

Jenis penelitian yang digunakan adalah penelitian deskriptif kualitatif. Penelitian dilakukan di Desa Toka Kecamatan Bulik Timur Kabupaten Lamandau. Teknik pengumpulan data dalam peneliti dilakukan dengan cara observasi, wawancara, dan studi kepustakaan. Analisis data yang digunakan dalam penelitian ini menggunakan metode analisis data kualitatif yaitu mendeskripsikan serta menganalisis data yang diperoleh di lokasi penelitian kemudian diolah dan ditabulasi berdasarkan sifat dan jenisnya selanjutnya di interpretasi secara deskriptif untuk menjawab rumusan masalah.

\section{HASIL PENELITIAN DAN PEMBAHASAN}

\section{Pelaksanaan Kewenangan Pemerintahan Desa dalam Bidang Kemasyarakatan di Desa Toka}

\section{Pembinaan Ketentraman dan Ketertiban Masyarakat}

Pada dasarnya ketentraman dan ketertiban adalah suatu keadaan yang aman dan teratur, tidak datang kerusuhan dan kekacauan sehingga daerah-daerah aman dan orang-orang didaerah tersebut bekerja dengan tenang dan teratur sesuai peraturan yang berlaku, menyebabkan terciptanya kelancaran pekerjaan. Jika dilihat dari kondisi Desa Toka sendiri memang terlihat rasa ketentraman dalam kehidupan masyarakatnya itu jelas terlihat dari masyarakat-masyarakatnya yang ramah tamah serta terbuka dengan orang baru dari pihak luar ataupun saya selaku pendatang yang ingin meneliti. Ketentraman di desa ini terjaga karena hal-hal yang bisa merusak ketentraman dan ketertiban desa seperti tindak kriminal sejauh ini belum pernah terjadi ini walaupun hal tersebut sampe saat ini desa masih amanaman saja tapi masyarakat desa tetap berjaga-jaga seperti halnya terlihat beberapa Pos keamanan yang dipergunakan masyarakat setempat sebagai pos untuk memantau lingkungan desa untuk mengantisipasi hal-hal yang tidak diinginkan terjadi sekaligus sebagai tempat ajang berkumpul anak muda.

\section{Pembinaan Partisipasi Warga}

Dari percakapan dan wawancara dengan kepala desa dan aparat desa mengenai persepsi masyarakat Desa Toka, yakni persepsi masyarakat dan persepsi pemerintah atau aparat desa. Peneliti dapat melihat Aparat pemerintah Desa Toka mengartikan partisipasi sebagai kemauan rakyat untuk mendukung suatu program yang direncanakan dari atas. Bukan dari masyarakat Desa Toka sendiri. Hal ini pada 
dasarnya adalah mobilisasi. Sedangkan pengertian partisipasi menurut persepsi masyarakat mengandung suatu pengakuan, kreativitas dan inisiatif dari rakyat sebagai modal dasar proses pelaksanaan pembangunan dan kegiatan sosial. Dengan demikian Intisari dari partisipasi peneliti amati, masyarakat menciptakan kegiatan sosial bukan selalu mendukung kegiatan-kegiatan sosial ataupun pembangunan. Jadi bentuk Partisipasi di Desa Toka yang dapat peneliti lihat yaitu partisipasi dari arahan pemerintah desa dan dari inisiatif masyarakat itu sendiri terlihat jelas. Namun, pada intinya keterlibatan masyarakat Desa Toka cukup besar dalam melaksanakan berbagai kegiatan sosial gotong royong jelas masih terlihat dalam kondisi desa.

\section{Faktor-Faktor Pendukung dan Penghambat Pelaksanaan Kewenangan Pemerintahan Desa dalam Bidang Kemasyarakatan}

\section{Faktor Pendukung}

Dalam melaksanakan pembinaan kepada para perangkat Desa Toka Kepala Desa khususnya telah melakukan berbagai cara untuk dapat membuat para perangkat desanya mampu melaksanakan tugas kemasyarakatan dengan baik. Beberapa cara yang dilakukan yaitu : (1) Kepala Desa memberikan pemahaman kepada perangkat desa agar dapat mengawasi keadaan lingkungan sekitar terutama dalam hal ketentraman dan ketertiban masyarakat desa namun dalam hal ketertiban pemilu para perangkat desa sangat tidak diperbolehkan untuk terlibat dalam berbagai kegiatan kampanye karena hal tersebut melanggar tata tertib dan peka terhadapnya serta memberikan pemahaman dalam pentingnya meningkatkan partisipasi masyarakat. (2) Memberi tugas perangkat desa untuk berkoordinasi dan bekerjasama dengan Binmas/Babinsa dalam melakukan pembinaan dan menjaga ketentraman dan ketertiban masyarakat desa. (3) Mengadakan evaluasi dan rapat kerja terhadap perkembangan hasil tugas yang telah dibebankan oleh kepala desa selaku pemimpin desa. (4) Perangkat desa ikut turut serta dalam berbagai pelatihan yang dilaksanakan ditingkat kabupaten atau kecamatan seperi halnya pelatihan madya yang diselenggarakan di tingkat kabupaten untuk meningkatkan mendorong peningkatan kapasitas masyarakat dan kapasitas aparatur desa.

Kecenderungan pendapat masyarakat menunjukkan bahwa upaya pemerintah desa dalam melibatkan tokoh masyarakat Desa Toka dalam kegiatan kemasyarakatan dinilai dengan nilai yang baik. Oleh karena itu, dengan baiknya penilaian masyarakat terhadap keterlibatan tokoh masyarakat maka pemerintah desa perlu mempertahankan pendapat masyarakat tersebut di dalam menjaga hubungan baik dengan tokoh masyarakat sebagai salah satu pihak yang dituakan di desa setempat.

Dari hasil pengamatan peneliti diketahui, bahwa Pemerintah Desa Toka telah mengupayakan secara nyata keterlibatan masyarakat secara langsung dalam menciptakan upaya menentramkan wilayah desa dan juga untuk mengupayakan masyarakat agar dapat ikut berpartisipasi dalam berbagai kegiatan secara gotong royong. Jawaban masyarakat menunjukkan bahwa upaya Pemerintah Desa Toka dalam melibatkan secara langsung masyarakat Desa Toka selama pelaksanaan dalam menciptakan ketentraman dan ketertiban masyarakat serta partisipasi masyarakat dalam kegiatan sosial sebagian besar responden menilai baik. Berdasarkan hasil wawancara diketahui bahwa adanya pendapat yang sama dalam 
menilai keterlibatan LKMD dan keterlibatan masyarakat dalam kegiatan kemasyarakatan desa. Masyarakat juga sangat turut berpartisipasi dalam pelaksanaan kegiatan-kegiatan yang dilaksanakan oleh pihak BPD ataupun LKMD yang ada di desa Toka.

\section{Faktor Penghambat}

Dari hasil pengamatan penulis selama penelitian, bahwa Pemerintah Desa Toka tidak berusaha menjalin dan mengitensifkan koordinasi dengan Binmas dan Babinsa, khususnya dalam ketentraman dan ketertiban masyarakat desa baik itu dari pemilihan kepala desa ataupun dari segi pembinaan keamanan masyarakat Desa Toka. Hal inilah yang kebanyakan terjadi di daerah pedesaan, karena masih banyaknya masyarakat yang belum mengerti tentang prosedur pembuatan sertifikat, apalagi tanah yang pemilik aslinya adalah orang tua mereka yang sudah tiada jadi batas-batas tanah yang mereka miliki malah saling diklaim oleh pihak lainnya. Kecenderungan pendapat masyarakat menunjukkan bahwa upaya pemerintah desa dalam menciptakan ketentraman dan ketertiban masyarakat di Desa Toka sebagian besar informan menilai kurang baik. Secara keseluruhan hasil penelitian ini menunjukkan bahwa pemerintah desa kurang berupaya melakukan koordinasi dengan anggota Babinsa dan binmas setempat.

\section{KESIMPULAN DAN SARAN}

Berdasarkan uraian pembahasan dalam skripsi ini, maka dapat ditarik beberapa kesimpulan bahwa pelaksanaan kewenangan Pemerintahan Desa dalam bidang kemasyarakatan mendukung peningkatan ketentraman dan ketertiban masyarakat Desa Toka berjalan baik terhindar dari segala ancaman kriminal, kecuali satu kasus masalah serobot tanah. Dalam hal peningkatan partisipasi masyarakat Desa Toka dirasa baik dalam pelaksanaannya.

a. Faktor pendukung berjalannya kewenganan Pemerintah Desa Toka adalah dengan Pembinaan terhadap BPD. Kepala Desa memberikan pemahaman kepada perangkat desa, memberi tugas perangkat desa untuk berkoordinasi dalam melakukan pembinaan dan menjaga ketentraman dan ketertiban masyarakat desa, mengadakan evaluasi dan rapat kerja, Perangkat desa turut serta dalam berbagai pelatihan dalam meningkatkan kapasitas masyarakat dan kapasitas aparatur desa.

b. Faktor penghambat pelaksanaan Pemerintahan Desa adalah Pemerintah Desa Toka tidak berusaha menjalin dan mengitensifkan koordinasi dengan Binmas dan Babinsa, khususnya dalam ketentraman dan ketertiban masyarakat desa baik itu dari pemilihan kepala desa ataupun dari segi pembinaan keamanan masyarakat Desa Toka.

Dalam rangka menstimulasi masyarakat agar mau berpartisipasi dalam bidang ketentraman dan ketertiban dan partisipasi masyarakat, diperlukan adanya rasa saling percaya antara pemerintah dengan masyarakat serta antar masyarakat. Pada sisi lain juga diperlukan peran, pembagian peran serta tanggung jawab disertai dengan hubungan yang jelas diantara para entitas. Pemerintah Desa diharapkan mampu berperan aktif dalam memberi pemahaman dan mengikut sertakan masyarakat. Pemerintah Desa perlu melakukan pertemuan dengan anggota Binmas/Babinsa setidaknya sebulan sekali, guna saling mengenal antara 
pemerintah desa setempat dengan anggota keamanan sehingga tidak ada lagi yang mengatakan bahwa tidak mengetahui anggota Babinsanya.

\section{DAFTAR PUSTAKA}

Abu Ahmadi, H. 2003. Ilmu Sosial Dasar, Jakarta : Gramedia.

Badudu J.S dan Zain, Sutan Mohammad. (1996). Kamus Umum Bahasa Indonesia. Jakarta: Pustaka Sinar Harapan.

Budiardjo, Miriam. 2004. Dasar-dasar Ilmu Politik. Jakarta : PT. Gramedia Pustaka Utama.

HP Arimbi dan Santosa A., 1993, Peran Serta Masyarakat Dalam Pengelolaan Lingkungan, Jakarta: WALHI.

Keputusan Menteri dalam Negeri Nomor 64 Tahun 1999 tentang Pedoman umum Pengaturan mengenai Desa.

Labolo, Muhadam, 2010. Memahami Ilmu Pemerintahan Suatu Kajian, teori, Konsep, dan Pengembangannya. Jakarta: Rajawali Pers.

Miles dan Huberman. 2007. Analisis Data Kualitatif. Jakarta: UI Press.

Mubyarto, 1984, Strategi Pembangunan Pedesaan, Yogyakarta: P3PK UGM.

Ndraha, Talizidhuhu. 1978. Pembangunan Masyarakat. Jakarta : Bina Aksara.

Pamudji, S. 1995, Kepemimpinan Pemerintahan Di Indonesia. Jakarta: Bumi Aksara.

Peraturan Pemerintah Nomor 25 Tahun 2000 tentang Kewenangan Pemerintah

Peraturan Pemerintah Nomor 43 Tahun 2014 tentang Peraturan Pelaksanaan Undang-Undang Nomor 6 Tahun 2014 tentang Desa.

Peraturan Pemerintah Nomor 72 Tahun 2005 tentang Desa

Permendesa Nomor 1 Tahun 2015 tentang Pedoman Kewenangan Berdasarkan Hak Asal Usul Dan Kewenangan Lokal Berskala Desa

Poerwadarminta. W.J.S. 2003. Kamus Umum Bahasa Indonesia. Jakarta: Balai Pustaka.

Rahardjo, Adisasmita. 2006. Membangun Desa Partisipatif, Yogyakarta: Graha Ilmu Yogyakarta.

Rama, Tri. 2010. Kamus Lengkap Bahasa Indonesia. Surabaya: Karya Agung.

Rasyid, Ryas. 1997. Makna Pemerintahan (Tinjauan Dari Segi Etika dan Kepemimpinan).Jakarta : PT Yasrif Watampone.

Soetomo, 2006. Strategi-strategiPembangunan Masyarakat, Yogyakarta : Penerbit Pustaka Pelajar.

Soetrisno, Loekman, 1995, Menuju Masyarakat Partisipatif, Penerbit: Kanisius, Yogyakarta.

Sugiyono, 2010. Metode Penelitian Kualitatif Kuantitatif dan R\&D. Bandung: CV.Alfabeta. 
Suharto, Edi. 2006. Membangun Masyarakat MemberdayakanRakyat. Bandung: PT.RefikaPratama.

Sulistyo, TrimiyatiJoko, http://trimiyati.web.ugm.ac.id/wordpress/?p=6

Surbakti, Ramlan. 1992. Memahami Ilmu Politik. Jakarta: PT GramediaWidiasarana Indonesia.

Sutoro Eko, 2014, Buku Pintar Kedudukan dan Kewenangan Desa, Penerbit: Forum Pengembangan Pembaharuan Desa (FPPD), Jakarta.

Syafei, Inu Kencana. 2005. Pengantar Ilmu Pemerintahan. Bandung: RefikaAditama.

Syarifin, Pipin. 2006. Pemerintahan Daerah di Indonesia. Bandung: Pustaka Setia.

Undang-Undang RI Nomor 12 Tahun 2008 tentang Pemerintah Daerah

Undang-Undang Dasar Negara Republik Indonesia 1945

Undang-Undang Nomor 6 Tahun 2014 Tentang Desa

Undang-Undang RI Nomor 23 Tahun 2014 tentang Pemerintahan Daerah

Widjaja, A.W, Administrasi Negara dalam kaitannya Dengan Penyelenggaraan Otonomi Daerah (Suatu Telaah Administrasi). Pidato Pengukuhan, Universitas Sriwijaya, Palembang, 22 September 1994.

Widjaja, A.W. 2001. Pemerintah Desa/Marga Menurut Undang-Undang Nomor 22 Tahun 1999 tentang pemerintahan Daerah, Jakarta: Penerbit PT Raja Grafindo Persada.

Widjaja, A.W. 2003. Otonomi daerah dan Daerah Otonom. Jakarta: Penerbit Raja Grafindo Persada.

Widjaja, A.W. Otonomi Desa merupakan Otonomi yang Asli,Bulat dan Utuh. Jakarta: Raja Grafindo Persada

Widjaja, A.W.2003. Otonomi Desa. Jakarta: Penerbit PT. Raja Garafindo Persada. 